\title{
Effects of marine reserves and urchin disease on southern Californian rocky reef communities
}

\author{
Michael D. Behrens ${ }^{1, *}$, Kevin D. Lafferty ${ }^{2}$ \\ ${ }^{1}$ Department of Ecology, Evolution and Marine Biology, and ${ }^{2}$ United States Geological Survey, Western Ecological Research \\ Center, c/o Marine Science Institute, University of California at Santa Barbara, Santa Barbara, California 93106, USA
}

\begin{abstract}
While the species level effects of marine reserves are widely recognized, community level shifts due to marine reserves have only recently been documented. Protection from fishing of top predators may lead to trophic cascades, which have community-wide implications. Disease may act in a similar manner, regulating population levels of dominant species within a community. Two decades of data from the Channel Islands National Park Service's Kelp Forest Monitoring database allowed us to compare the effects of fishing and urchin disease on rocky reef community patterns and dynamics. Different size-frequency distributions of urchins inside and outside of reserves indicated reduced predation on urchins at sites where fishing removes urchin predators. Rocky reefs inside reserves were more likely to support kelp forests than were fished areas. We suggest that this results from cascading effects of the fishery on urchin predators outside the reserves, which releases herbivores (urchins) from predation. After periods of prevalent urchin disease, the reef community shifted more towards kelp forest assemblages. Specific groups of algae and invertebrates were associated with kelp forest and barrens communities. The community dynamics leading to transitions between kelp forests and barrens are driven by both fishing and disease; however the fishery effect was of greater magnitude. This study further confirms the importance of marine reserves not only for fisheries conservation, but also for the conservation of historically dominant community types.
\end{abstract}

KEY WORDS: Marine reserves $\cdot$ Kelp forest · Urchin barrens $\cdot$ Disease $\cdot$ Rocky reefs $\cdot$ Community description · Discriminant analysis

Resale or republication not permitted without written consent of the publisher

\section{INTRODUCTION}

Shallow rocky reefs in temperate regions often exist in 1 of 2 states: kelp forests or urchin barrens (Paine \& Vadas 1969, Harrold \& Reed 1985, Schiel \& Foster 1986, Elner \& Vadas 1990, Skadsheim et al. 1995, Scheibling \& Hennigar 1997, Estes et al. 1998, Sala et al. 1998, Babcock et al. 1999, Tegner \& Dayton 2000). Several circumstances can create conditions where sea urchins overgraze the standing stock of fleshy algae that normally create kelp forests (Watanabe \& Harrold 1991, Sala et al. 1998, Tegner \& Dayton 2000). Continued grazing by sea urchins prevents the reestablishment of fleshy algae and promotes the establishment of crustose coralline algae that are more resistant to grazing (Harrold \& Reed 1985). Because barrens and forests provide different socioeconomic values and ecological functions, a better understanding of the underlying mechanisms behind the maintenance of, or transition between, both states is of interest.

The effectiveness of marine reserves has become a major research priority in marine ecology. Marine reserves are often established with the goals of fisheries enhancement or biodiversity conservation. Many studies indicate that reserves increase the density and size of exploited species within the reserve (Halpern \& Warner 2002). Recently, studies have also begun to address biodiversity conservation through communitywide changes due to marine reserves. Community state transitions between barrens and kelp forests due to marine reserves have been documented on temperate rocky reefs in New Zealand (Babcock et al. 1999, 
Shears \& Babcock 2002). This appears to be due to indirect effects of the fishery, which cascade down the food chain to produce a community shift (fisherylobsters-urchins-kelp: Shears \& Babcock 2002, 2003). Tethering experiments indicate that predation rates on urchins by lobsters are much greater inside than outside reserves (Shears \& Babcock 2002).

In the Channel Islands off southern California, a similar scenario occurs (Lafferty 2004). Where purple urchins are abundant, algae are rare, suggesting that high urchin abundances lead to barrens. In southern California, commercial and recreational fisheries have an impact on urchin predators, taking a very high fraction of spiny lobsters Panulirus interruptus over the legal size limit (Tegner \& Levin 1983). In addition, sheephead Semicossyphus pulcher are speared and trapped outside the reserves (Tegner \& Dayton 2000). Urchin recruitment does not differ between reserves and fished areas (Lafferty 2004). In reserves, lobster abundance is high, purple urchins are rare and algae are abundant, suggesting that predation on urchins may establish a trophic cascade that leads to the formation of kelp forests (Lafferty 2004). While, sheephead have been found to significantly reduce urchin populations, sheephead abundance is similar inside and outside reserves, indicating that their interaction in this trophic cascade might be limited (Cowen 1983, Lafferty 2004). However, if sheephead are larger within the reserve, their predation pressure may be greater inside the reserve than in adjacent fished areas. Sea urchin size distributions can provide additional indirect evidence of the intensity of predation (Tegner \& Dayton 1981, Tegner \& Levin 1983, Cole \& Keuskamp 1998). A bimodal size frequency distribution is caused in the sea urchin population by a spatial refugium from predation for the smallest size classes (within the spine canopy of large adults), and by a size refugium from predation for the largest size classes. Where urchin predators are rare, size frequency distributions are normal or lognormal.

Disease and parasitism lead to declines in urchin populations (Lessios et al. 1984, Skadsheim et al. 1995, Scheibling \& Hennigar 1997). Bacterial epidemics are frequent outside of reserves where urchins are common and lead to decreases in urchin abundance (Lafferty 2004). Disease symptoms at the Channel Islands (spine loss, tissue damage represented by dark blotches on the test; Richards \& Kushner 1994) are most consistent with Vibrio bacteria (Gilles \& Pearse 1986). The most common host is the purple urchin Strongylocentrotus purpuratus; 2 less-common sympatric species, S. franciscanus and Lytechinus anamesus, also suffer from disease. This is often fatal, as evidenced by the high number of recently dead and dying animals during the peak of an epidemic, although the presence of urchins re-growing spines after an epidemic indicates that some of them recover (Richards \& Kushner 1994). Although disease reduces sea urchin densities (Lafferty 2004), it is not clear whether this is enough to maintain kelp forests on rocky reefs.

Kelp forests and barrens are visually distinct, but only recently has there been quantitative evidence illustrating species associations with these 2 community types, involving a diverse array of taxa (Holbrook et al. 1990, Graham 2004). Using presence-absence data from the California Channel Islands, Graham (2004) determined that many species show clear associations with the 2 community types and that on average diversity declines by $35 \%$ in the transition from kelp forest to barrens community. He further concluded that, while it is possible to show associations using presence-absence data, using abundance data to determine species associations will lead to a better understanding of the ecological consequences of kelp loss to rocky reef communities (Graham 2004).

We investigated 4 questions about causes and consequences of the barrens-kelp forest dichotomy at the Channel Islands: (1) Does fishing reduce predation on urchins? (2) Does fishing shift rocky reef communities from kelp forests to barrens? (3) Does urchin disease shift rocky reef communities from barrens to kelp forests? (4) Do species abundance patterns differ between barrens and kelp forests?

\section{MATERIALS AND METHODS}

Dataset. We used data collected and provided by the Channel Islands National Park (CINP) long-term KelpForest Monitoring Program (KFM). The CINP established the KFM in 1982 (Davis et al. 1997). The KFM annually samples 16 rocky reef sites from the north and south sides of Santa Barbara, Anacapa, Santa Cruz, Santa Rosa and San Miguel Islands (1 to 3 visits per summer) (Fig. 1); 2 of these sites (Fig. 1, Sites 12 and 13) occur inside the Anacapa Island Ecological Reserve established in 1978. The sites can be roughly grouped into 2 biogeographic regions based on water temperature (Reed et al. 2000). The 6 sites in the west are colder and have somewhat different faunal compositions than the 10 warmer eastern sites (Fig. 1). To ensure generality of the results across the region, we used data from all 16 sites to produce a linear discriminant function and determine species associations between kelp forests and barrens. However, we limited our reserve and disease analyses to the warmwater sites due to differences in dominant predators and disease dynamics between the 2 regions. Each site consists of a $100 \mathrm{~m}$ permanent transect. The KFM uses a variety of methods to quantify taxa such as kelps, 
urchins, sea stars, lobsters and fishes. Annual reports from 1990 to 1999 (e.g. Richards \& Kushner 1994) describe each year's monitoring efforts and results. For example, divers count urchin densities using 12 to 40 quadrats of 1 to $2 \mathrm{~m}^{2}$, spaced along each transect, reporting densities as ind. $\mathrm{m}^{-2}$. The KFM sampled a limited number of taxa from 1982 to 1984, while a more extensive list of taxa was sampled after 1985; our study uses these later data. We transformed the densities using $\log +1$ and angular transformation of percentage covers. After 1990, divers also qualitatively described each site as a type of barrens, forest, or intermediate.

Does fishing reduce predation on urchins? In the reserves, lobster densities but not sheephead densities are high, and

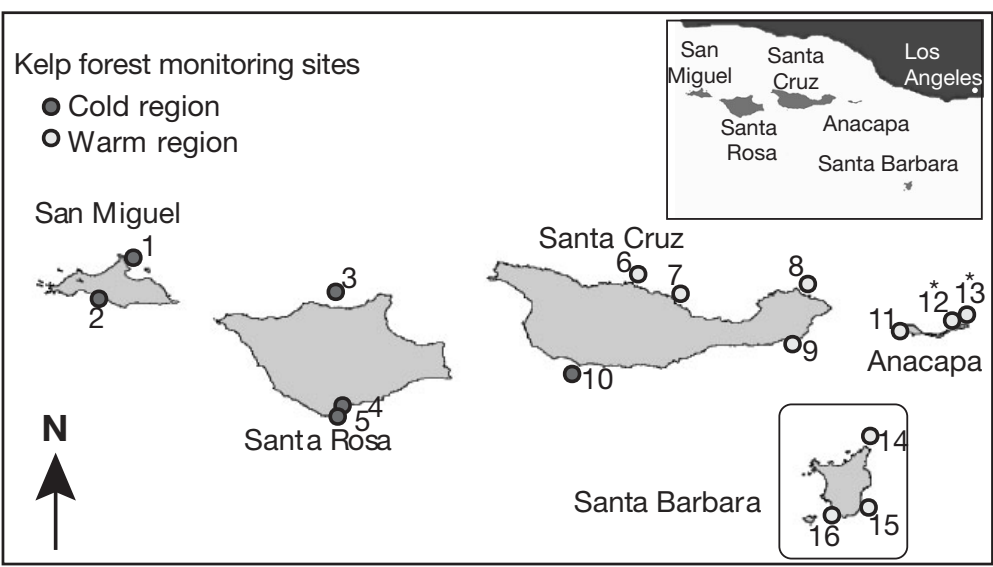

Fig. 1. Kelp Forest Monitoring Program sites at the California Channel Islands. (0) Sites used in the analyses (excluding Site 11). (0) Sites excluded due to differences in water temperature and depth. (*) Sites in a small marine reserve established in 1978 urchin densities are low (Lafferty 2004). To

seek insight into whether this is a result of increased predation pressure on urchins in the reserves, we plotted size frequency distributions for the 2 common urchin species (Strongylocentrotus franciscanus and $S$. purpuratus) at reserve and fished sites to determine whether they indicated any differences in predation pressure. To produce the size frequency distributions, we combined all size frequency data for a species across sites and years. These distributions are stable over time (Tegner \& Dayton 1981, Tegner \& Levin 1983), and the between-site differences were minimal within either reserves or fished areas.

Quantifying forests and barrens. KFM reports did not always clearly classify the sites that were monitored. This included 18 site-year combinations between 1990 and 2001, and all 78 site-year combinations from 1985 to 1989. Simple indices such as density of kelp or urchins were not sufficient to classify these sites (the density of kelp plants declines as forests mature, and some kelp forests can support high urchin densities). To determine the state of the 96 unclassified site-year combinations, we conducted a Fisher's linear discriminant analysis that described and distinguished between sites that were clearly categorized as forests $(\mathrm{N}=88)$ or barrens $(\mathrm{N}=86)$. A simple linear discriminant function of 2 groups uses a linear combination of variables $\left(X_{1}=\right.$ measurement 1$)$ with weights $\left(\mathrm{a}_{\mathrm{i}}\right)$ for each variable $X$ chosen to maximize the separation between 2 groups (A and B). A canonical score, $d$, is produced by the function $\mathrm{a}_{0}+\mathrm{a}_{1} X_{1}+\mathrm{a}_{2} X_{2}+\ldots+\mathrm{a}_{\mathrm{n}} X_{\mathrm{n}}$, for a given set of $X$ values (Klecka 1980, McGarigal et al. 2000). Ranking the taxa included in the discriminant function by their standardized weights, along with stepwise procedures, helped us determine which taxa were most useful in discriminating among groups, i.e. the best indicator taxa (Klecka 1980). We used a jackknife procedure to estimate classification success, i.e. the proportion of times the analysis properly identified the reported classification of a site-year combination that had been removed prior to developing the function.

The canonical scores resulting from the discriminant function provided a gradient within community states (McGarigal et al. 2000, SPSS 2000), allowing us to describe rocky reef communities along a continuum from kelp forests to barrens. This reduced the dimensionality of the large number of species densities and percent covers with a minimum loss of information (Klecka 1980, McGarigal et al. 2000). The canonical scores provided a basis for subsequent analyses of species associations with kelp forests, the effects of reserves and the effects of disease. To verify whether intermediate canonical scores were a biologically meaningful gradient between barrens and forests (Williams 1983), we extracted finer-scale classifications of the community states from the KFM reports (Table 1). These classifications took into account the density and age of kelp, mosaics of barrens and forests, and dominant species in barrens. We then calculated the mean canonical score and SE for each classification and plotted them against the finer-scale community states.

Does fishing shift rocky reefs from kelp forests to barrens? To determine whether fishing affected the community state of rocky reefs, we performed a repeated measures ANOVA on the canonical scores for reserves and fished sites, controlling for site as a random factor. For the analysis, sites were classified as 'reserve' or 'fished'. To control for the possibility that fished sites were initially different from the reserve 
Table 1. Community states from the Kelp Forest Monitoring annual reports. In the discriminant analysis we used the 88 site-year combinations clearly classified as kelp forests and 86 site-year combinations clearly classified as barrens; we excluded the 18 transition (1990 to 2001) and the 78 unclassified (1985 to 1989) site-year combinations. N: no. of sites

\begin{tabular}{|lrl|}
\hline Community state & N & \multicolumn{1}{c|}{ Description } \\
\hline Forest & & \\
$\quad$ Mature kelp forest & 40 & High densities of mature kelps and kelp-forest associated invertebrates \\
$\quad$ Developing kelp forest & 14 & High densities of young kelps and some barrens-associated invertebrates \\
Kelp forest & 19 & Uniform low kelp densities and kelp-forest associated invertebrates \\
$\quad$ Sparse kelp forest & 88 & \\
Total & & \\
Transition & 3 & Kelp forests with abnormally high densities of urchins \\
Kelp forest with urchins & 12 & Open areas without kelp, but with high cover of fleshy algae \\
Open area with algae & 18 & Patches of kelp forest interspersed with barrens \\
Sparse kelp forest/barrens & & \\
Total & 12 & Dominated by Pachythione rubra \\
Barrens & 12 & Dominated by Strongylocentrotus franciscanus \\
$\quad$ Pachythione barrens & 23 & Dominated by a mix of urchin species \\
Red urchin barrens & 33 & Dominated by Strongylocentrotus purpuratus \\
Urchin barrens & 6 & Dominated by S. purpuratus and Ophiothrix spiculata \\
Purple urchin barrens & 86 & \\
$\quad$ Echinoderm barrens & 78 & \\
Total & & \\
Unclassified &
\end{tabular}

sites, we subdivided the fished sites into those that were clearly kelp forests at the beginning of the study and those that were in an intermediate state. The 2 reserve sites were situated at different reefs, but within a single reserve. We confirmed that the 2 sites varied substantially in habitat characteristics and that they did not significantly covary over time (canonical scores: $\mathrm{r}=0.06, \mathrm{~N}=17, \mathrm{p}=0.817$; canonical score change: $r=0.12, \mathrm{~N}=17, \mathrm{p}=0.656$ ) before treating them as independent replicates in the analyses. We also confirmed that using an average of the 2 sites yielded qualitatively similar results as treating them separately.

Does urchin disease shift rocky reefs from barrens to kelp forests? To determine whether an outbreak of urchin disease affects the community state, we determined the subsequent change in canonical score. Sites were limited to those that experienced disease outbreaks during 1992 to 2001: Site 7 (1993-98, 2000), Site 8 (1994, 1996-98, 2000), Site 9 (1992, 1994, 1996-97, 2000), Site 10 (1996, 1998-00), Site 11 (1992-00), Site 13 (1993-94), Site 14 (1993-96, 1999-00), Site 15 (1992-93, 1995-98, 2000), Site 16 (1992-93, 1997-00). To obtain a canonical gradient independent of urchin densities, we first produced a generic function (general-taxon model) using composite faunal groups generally associated with barrens (bare substrate and crustose coralline algae) or forests (all fleshy algae). Sea urchins, the grazers most frequently implicated in shifts between kelp forests and barrens, were omitted from this function so that we could investigate changes in the community state due to urchin disease that would be independent of declines in urchin density due to mortality from disease.

We then performed a regression of the change in this general-taxon canonical score against a rank score of disease prevalence. We defined the prevalence ranks as an ordinal scale based on the percentage of infected urchins ( $1=1$ to $25 \%, 2=26$ to $50 \%, 3=51$ to $75 \%, 4$ $=76$ to $100 \%$ infected; see Lafferty 2004). The regression model also included the canonical score in the year of the outbreak as an effect to control for the tendency for extreme canonical scores to be more likely to return to intermediate scores due to random walk dynamics. Each observation was treated as independent after a temporal autocorrelation analysis revealed no significant correlations for any time lags for either prevalence or canonical score change.

Do taxa differ between barrens and forested states? We conducted a partial correlation analysis to ascertain whether some rocky reef taxa were more closely associated with kelp forests or with barrens. The partial correlation analysis assessed whether there was a significant relationship between a taxon (density or percentage cover) and the canonical score (forest to barrens continuum), while controlling for site and year. We included all sites and years in this analysis ( $\mathrm{N}=$ 266) to determine whether any observed association was consistent across the northern Channel Islands. 
We excluded those taxa included in the discriminant analysis from the partial correlation analysis due to the lack of independence between their density or percentage cover and the canonical score. To meet the assumptions of partial correlation analysis, we used log-transformed density, and angular transformation of percentage cover data. By definition, species associated with kelp forests had a significant positive correlation. Species associated with barrens had a significant negative correlation. Significance levels were sequential Bonferroni corrected (Rice 1989) to maintain an overall significance level of 0.05 within each group (algae, invertebrates, and fishes).

\section{RESULTS}

\section{Does fishing reduce predation on urchins?}

Sea urchin Strongylocentrotus franciscanus and $S$. purpuratus size frequency distributions within the reserve were bimodal, while the size frequency distributions in fished areas were unimodal (Fig. 2). Based on work by Tegner \& Dayton (1981) and Tegner \& Levin (1983), this is consistent with the hypothesis that predation on urchins was lower at fished sites compared to reserve sites.

\section{Classification of communities by discriminant analysis}

Classification success reached a maximum of $97 \%$ for the top 7 taxa, a $94 \%$ improvement over the expected success using random assignment to groups $\left(\mathrm{r}=0.94, \mathrm{r}_{\mathrm{K}}=0.94, \mathrm{p}<0.001\right)$ (Cohen 1960, McGarigal et al. 2000). The 7 most useful factors (including unstandardized canonical coefficients, constant $=4.17$ ) were, in order of importance (large species as ind. $\mathrm{m}^{-2}$, cover as percentage): giant kelp Macrocystis pyrifera (2.90), purple urchins Strongylocentrotus purpuratus $(-0.97)$, cover of bare substrate $(-3.48)$, cover of anemones Corynactis californica (-5.25), cover of cup coral Astrangia lajollaensis (-6.03), cover of the bryozoan Diaperoecia californica (5.53), and cover of crustose coralline algae (-1.67). M. pyrifera and D. californica were associated with kelp forests, while $S$. purpuratus, C. californica, A. lajollaensis, crustose coralline algae, and bare substrate were associated with barrens.

The gradient between forests and barrens was clear, with forests as positive values and barrens as negative values (Fig. 3). Values near zero represented intermediate (mixed communities at a site), or transitional community states. Kelp forests with high urchin densities and open areas with abundant benthic algae had small positive values, while sparse kelp forests within a mosaic of barrens had small negative values. The gradients within forests and barrens were not as clear, but they did describe the community composition and, to some extent, the development of the kelp forest community. Within forests, there was a decline in the canonical score from mature forests to developing forests, to sparse forests, to open areas with some benthic algae. Mature kelp forests have relatively low kelp densities and invertebrate communities typical of kelp forest communities. Developing kelp forests usually have high densities of kelp, but may not have lost some of the invertebrates associated with barrens. Sparse

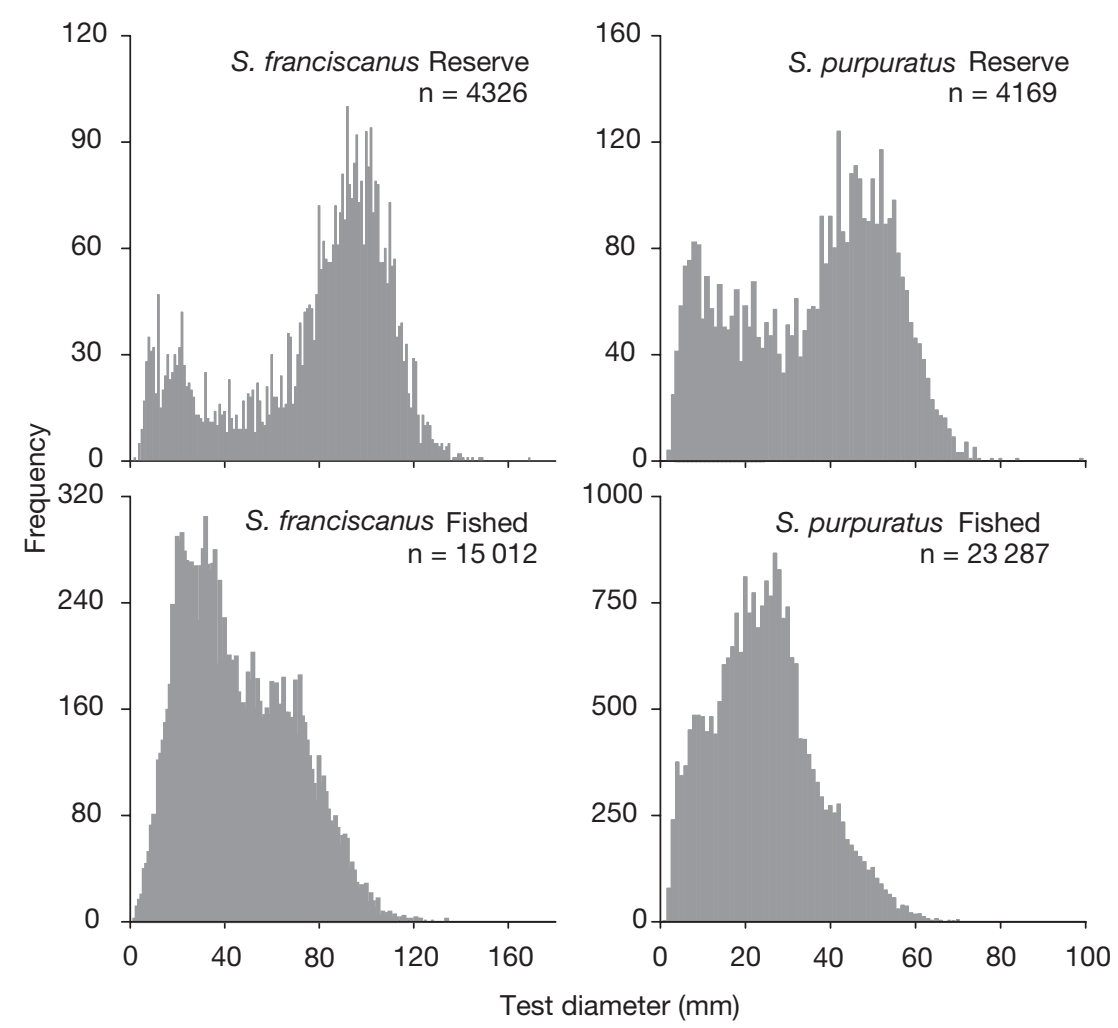

Fig. 2. Strongylocentrotus franciscanus and Strongylocentrotus purpuratus. Urchin population size structure at reserve (upper panels) and fished (lower panels) Kelp Forest Monitoring Program sites. Size data were pooled across site and year, since urchin size frequency distributions are stable over time (Tegner \& Levin 1983). We plotted size frequency distributions across site and year separately to confirm that these patterns are consistent within individual sites and years 


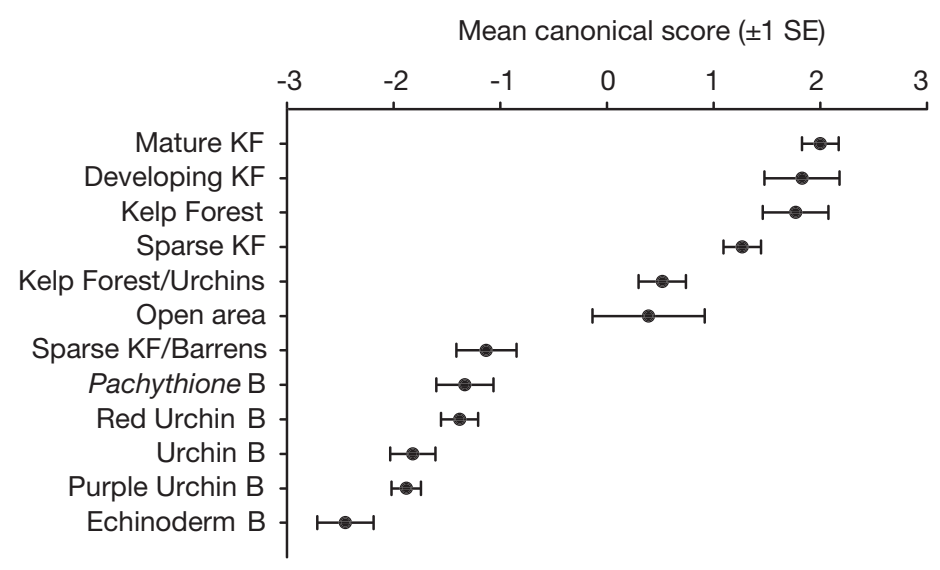

Fig. 3. Canonical scores (mean $\pm \mathrm{SE}$ ) for the community states derived from the annual Kelp Forest Monitoring Program reports. KF: kelp forest; B: barrens. See Table 1 for descriptions

kelp forests having invertebrates associated with barrens had intermediate canonical scores. Open areas with benthic algae lacked both kelps and barrensassociated invertebrates and, consequently, also had intermediate canonical scores.

Barrens varied in canonical score in relation to the composition of barrens-forming echinoderms. Sea cucumber Pachythione rubra barrens retained small amounts of benthic algae and, therefore, had the least extreme mean canonical score. Strongylocentrotus franciscanus barrens had more extreme canonical scores and $S$. purpuratus barrens had even more extreme canonical scores. Urchin barrens dominated by a mixture of Lytechinus anamesus, S. franciscanus and $S$. purpuratus had canonical scores intermediate to those of $S$. franciscanus and $S$. purpuratus barrens. Echinoderm barrens dominated by urchins and brittle stars (predominantly Ophiothrix spiculata) had the most extreme canonical score; these communities usually had low diversity and were comprised of encrusting coralline algae and bare substrate.

\section{Does fishing shift rocky reefs from kelp forests to barrens?}

Sites within the reserve were more likely to be kelp forests, and fished sites were more likely to be barrens. Fished sites were commonly urchin barrens, regardless of whether or not they started the study as kelp forests (Fig. 4) (ANOVA, $F_{2,6}=10.61, p=0.011$ ). Reserves had greater canonical scores than fished sites that had initially been kelp forests
$\left(F_{1,6}=17.26, \mathrm{p}=0.012\right)$ or mosaics of forests and barrens $\left(F_{1,6}=21.197, \mathrm{p}=0.011\right)$. Fished sites that were initially kelp forests had similar canonical scores to those that were initially barrens or mosaics of barrens and forest $\left(F_{1,6}=\right.$ $0.06, \mathrm{p}=0.809$ ). Although there was noticeable temporal synchrony across all the sites, likely due to larger scale influences such as ENSO events, reserve sites were more resilient to change and never became barrens.

\section{Does urchin disease shift rocky reefs from barrens to kelp forests?}

The general-taxon model constructed for the disease analysis correctly classified approximately $90 \%$ of the site-year combinations. The model (including unstandardized canonical coefficients, constant $=1.11$ ) included cover of bare substrate $(-2.93)$, cover of crustose coralline algae $(-1.85)$, and cover of fleshy algae (2.82), where fleshy algae were correlated with forests, while bare substrate and crustose coralline algae were correlated with barrens. We note that this model, which is not taxon specific, could well describe barrens throughout the world.

An analysis of the effect of disease prevalence on kelp forest-barrens dynamics showed that the positive change in canonical score (after controlling for the effect of the canonical score) between one year and the

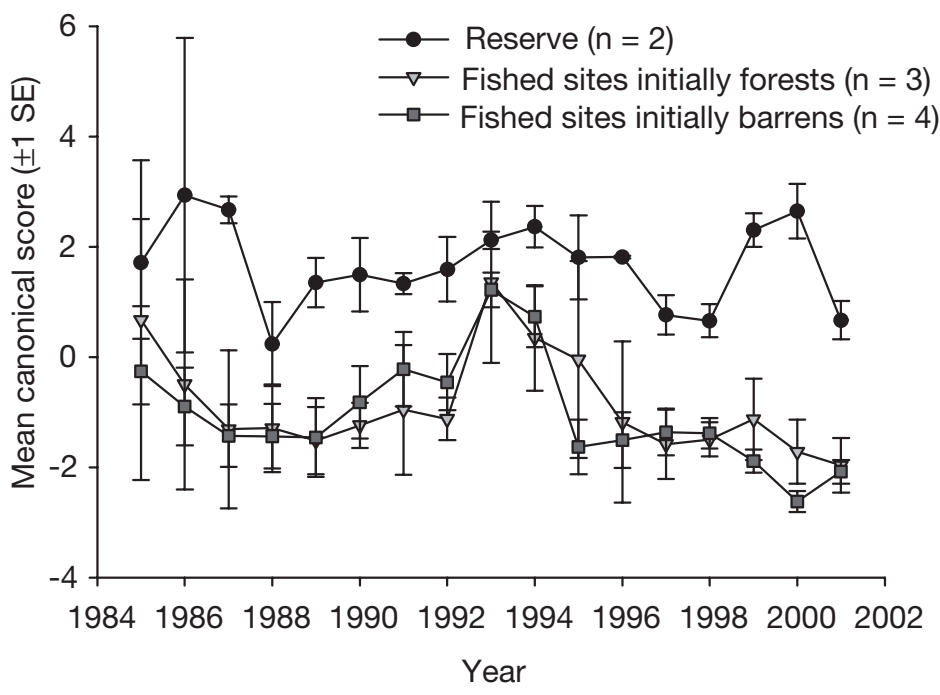

Fig. 4. Canonical scores (mean $\pm \mathrm{SE}$ ) plotted over time for reserve sites (12 and 13), fished sites that were initially kelp forests (Sites 7, 8, 16), and fished sites that were initially mosaics of forests and barrens (Sites 6, 9, 14, 15) 
next increased with the prevalence of disease in the initial year (Fig. 5) $\left(\mathrm{r}^{2}=0.26, F_{1,49}=17.79, \mathrm{p}<0.001\right)$. This shows that disease shifted sites toward, but not necessarily to, a kelp forest community.

\section{Do taxa differ between barrens and kelp forests?}

By definition, crustose coralline algae and bare substrate predominated in barrens, while all of the kelps and most of the algal taxa were common in kelp forests (Table 2). Among the invertebrates, urchins Strongylocentrotus spp. and Lytechinus anemesus, small anemones (Corynactis californica and Astrangia lajollaensis), gorgonians, and predatory gastropods (Kelletia kelletii and Cypraea spadicea) were associated with barrens. The major urchin predators (Panulirus interruptus and Pycnopodia helianthoides), fished mollusks (Haliotis corrugata and Crassedoma giganteum),

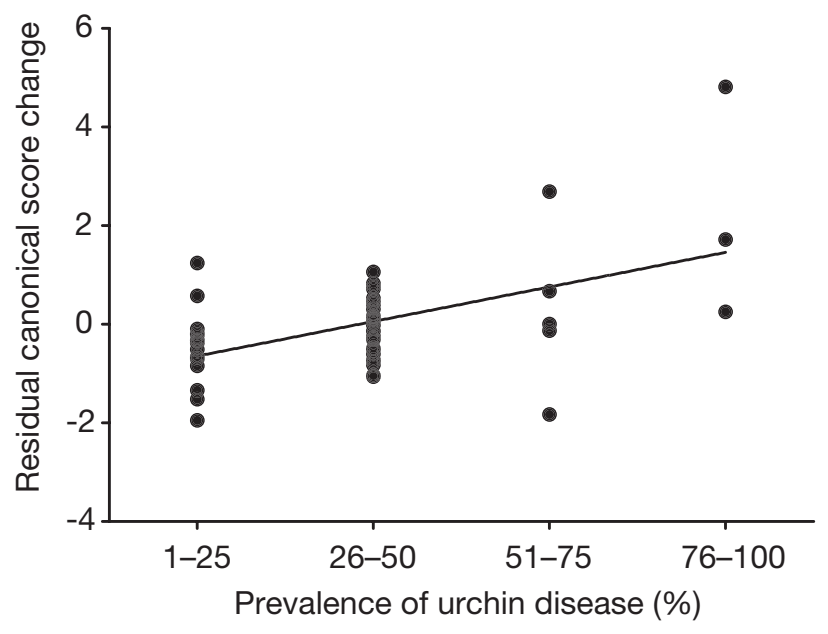

Fig. 5. Residual change in canonical score plotted against the prevalence of urchin disease, after removing the effect of canonical score in the year of the outbreak $\left(\mathrm{r}^{2}=0.26, \mathrm{~N}=51\right.$, $\mathrm{p}<0.0001)$

Table 2. Associations between taxa and rocky reef states. Partial correlation results of species densities and canonical scores controlling for site and year. Species are ranked in descending order based on thestrength of the association. Some taxa (*) were included in discriminant analysis and therefore excluded from partial correlation analysis due to lack of independence

\begin{tabular}{|c|c|c|c|}
\hline & Correlated with barrens & Not correlated & Correlated with kelp forests \\
\hline \multirow[t]{2}{*}{ Algae } & & $\begin{array}{l}\text { Gigartina spp. } \\
\text { Miscellaneous plants } \\
\text { Miscellaneous green algae } \\
\text { Gelidium spp. }\end{array}$ & $\begin{array}{l}\text { Cystoseira spp. } \\
\text { Miscellaneous red algae } \\
\text { Laminaria farlowii } \\
\text { Miscellaneous brown algae } \\
\text { Pterogophora californica } \\
\text { Eisenia arborea } \\
\text { Desmarestia spp. } \\
\text { Articulated coralline algae }\end{array}$ \\
\hline & $\begin{array}{l}\text { Crustose coralline algae } \\
\text { Bare substrate }^{\star}\end{array}$ & & Macrocystis pyrifera \\
\hline \multirow[t]{2}{*}{ Invertebrates } & $\begin{array}{l}\text { Strongylocentrotus franciscanus } \\
\text { Gorgonians } \\
\text { Kelletia kelletii } \\
\text { Pisaster giganteus } \\
\text { Lytechinus anamesus } \\
\text { Aplysia californica } \\
\text { Cypraea spadicea }\end{array}$ & $\begin{array}{l}\text { Pachythione rubra } \\
\text { Megathura crenulata } \\
\text { Stylaster californica } \\
\text { Lithopoma undosum } \\
\text { Balanophyllia elegans } \\
\text { Tethyia aurantia } \\
\text { Parastichopus parvimensis } \\
\text { Asterina miniata } \\
\text { Serpulorbis squamigerous } \\
\text { Miscellaneous invertebrates }\end{array}$ & $\begin{array}{l}\text { Bryozoans } \\
\text { Sponges } \\
\text { Phragmatopoma californica } \\
\text { Urticina lofotensis } \\
\text { Haliotis corrugata } \\
\text { Crassedoma giganteum } \\
\text { Pycnopodia helianthoides } \\
\text { Panulirus interruptus }\end{array}$ \\
\hline & $\begin{array}{l}\text { Strongylocentrotus purpuratus } \\
\text { Astrangia lajollaensis* } \\
\text { Corynactis californica }^{\star}\end{array}$ & & Diaperoecia californica* \\
\hline Fishes & $\begin{array}{l}\text { Coryphopterus nicholsi } \\
\text { Lythrypnus dalli } \\
\text { Chromis punctipinnus } \\
\text { Sebastes mystinus }\end{array}$ & $\begin{array}{l}\text { Embiotoca lateralis } \\
\text { Sebastes serranoides } \\
\text { Paralabrax clathratus } \\
\text { Damalichthys vacca } \\
\text { Girella nigricans } \\
\text { Semicossyphus pulcher } \\
\text { Alloclinus holderi } \\
\text { Embiotoca jacksoni } \\
\text { Oxyjulis californica } \\
\text { Sebastes atrovirens } \\
\text { Hypsypops rubicundus }\end{array}$ & \\
\hline
\end{tabular}


sponges, colonial tube worms (Phragmatopoma californica), and bryozoans (an unidentified complex of bryozoans and Diaperoecia californica) were associated with kelp forests. There were few clear patterns of association in the data on fishes. Two of the fishes associated with barrens (Coryphopterus nicholsi and Lythrypnus dalli) are cryptic benthic species that are easier to count in barrens than in kelp forests. Surprisingly, there were no fish species significantly associated with kelp forests, e.g. the urchin predator Semicossyphus pulcher and the herbivore Girella nigricans.

\section{DISCUSSION}

This study used a quantitative description of rocky reef community states at the California Channel Islands to determine the effects of fishing and disease. Fishing reduced the abundance of lobsters and other target invertebrates, thus releasing urchins from predation. Urchins increased in number at fished sites, and this led to often dramatic changes, shifting rocky reefs from kelp forests to barrens. These contrasting community states were associated with different invertebrate and algal taxa. In barrens, conditions were ripe for epidemics of urchin disease, which shifted rocky reefs back toward kelp forests. There was also largescale temporal synchrony in the kelp forest-barrens dynamics that was likely due to large-scale oceanographic processes, such as transitions towards kelp forests following the 1992 ENSO event and the transition towards barrens states during the 1987 ENSO event (Fig. 4).

\section{Fishing reduces predation on urchins}

The strongest predation effect on purple urchins appears to be from large spiny lobsters Panulirus interruptus; however, sheephead Semicossyphus pulcher may also play an important role. Outside the reserve, commercial and recreational fisheries take a very high fraction of the spiny lobsters over the legal size limit (Tegner \& Levin 1983). Concomitant with patterns in predator abundance, predation intensity on sea urchins appears to be lower in fished areas, as evidenced by shifts in the sea urchin size distribution. This result confirms tethering experiments that show that the establishment of reserves which protect lobsters can increase the rate of predation on urchins (Shears \& Babcock 2002). In reserves, predation can mask the effect of large temporal and spatial variation in urchin recruitment, and keep adult urchin population density low (Lafferty \& Kushner 2000). The effects of the establishment of a reserve on the larger red sea urchin Strongylocentrotus franciscanus are difficult to intepret, because this species is subject to an intensive fishery. In addition, red urchins may compete with purple urchins (Ebert 1977), enhancing the indirect effects of the fishery on purple urchin densities.

While other urchin predators are common in this ecosystem, their relative densities inside and outside of reserves do not appear to be directly altered by fisheries, and their role in controlling urchin populations inside the reserves is unclear. Sheephead Semicossyphus pulcher are speared and trapped outside of reserves (Tegner \& Dayton 2000), but they were not more abundant in the reserves. Sheephead are known to limit urchin populations (Cowen 1983, Lafferty 2004) and if sheephead are larger within the reserve, the predation pressure on urchins due to this species might be greatest within reserves. Additionally, due to the highly mobile nature of this species, the density patterns discussed above may be due to movement of this species to areas with higher urchin densities in fished areas. The predatory seastar Pycnopodia helianthoides can affect sea urchin densities at more temperate sites where lobsters are rare (Duggins 1983, Lafferty \& Kushner 2000), but this seastar is not fished.

\section{Fishing shifts rocky reefs from kelp forests to barrens}

When the KFM sites were chosen just before monitoring, all rocky reefs were kelp forests at various stages of development. Differences between reserve and fished sites only became apparent after the 1982/83 ENSO event (M. D. Behrens \& K. D. Lafferty unpubl. data). Subsequently, reserve sites always remained kelp forests, while fished sites were typically barrens, but they occasionally became forests during years of large-scale kelp reestablishment.

Many different factors lead to changes in urchin abundances and transitions between kelp forest and barrens communities, including, but not limited to, reduction of urchin predators, disease, recruitment, oceanographic events, and urchin harvesting (Sala et al. 1998). Community state transitions between barrens and kelp forests due to marine reserves have been documented on temperate rocky reefs in New Zealand (Babcock et al. 1999, Shears \& Babcock 2002). In both that system and the system in this study, the effects appear to be due to a top-down effect of the fishery cascading down the food chain to produce a community shift.

Shifts in the community at a site due to changes in predator abundances and to reserves are not limited to temperate rocky reefs. The presence or absence of crab predation in salt marshes in the SE United States leads to transitions between Spartina dominated sites 
and mudflats (Silliman \& Bertness 2002). On Kenyan coral reefs, fishing of herbivorous fishes leads to a more developed algal community that excludes corals (McClanahan et al. 1996); unfished sites also have higher coral cover and substrate complexity because predatory fish limit urchin densities (McClanahan \& Shafir 1990). In the NW Mediterranean, fishing reduces the abundance of predatory fish, leading to an increase in the dominant urchin species and a change in benthic community composition (Sala \& Zabala 1996). In conclusion, our results are consistent with a growing number of studies that indicate how reserves can indirectly preserve historical community states by protecting predators from fishing.

\section{Urchin disease shifts rocky reefs from barrens to kelp forests}

While disease and predation both act to control urchin abundances, they do so by different mechanisms. Disease is rare at reserve sites but common at fished sites, where predator abundance is too low to keep urchin densities below a critical density threshold. Lafferty (2004) found that disease reduces the abundance of urchins at a site, but not to the same extent as predation. The more prevalent the disease was at a site, the more that site shifted towards a kelp forest the following year. While predators feed on urchins regardless of the abundance of urchins at the site, only sites with high urchin abundances are susceptible to disease (Lafferty 2004). These sites with high urchin abundances are often well-established barrens that require not only a reduction in urchin abundances, but also a source of algal propagules for kelp forest reestablishment. Only those disease outbreaks with the highest prevalence of infected individuals caused transitions from barrens to kelp forests.

Community transitions due to disease occur in both temperate and tropical habitats. Severe disease outbreaks of a marine amoeba in Nova Scotia populations of Strongylocentrotus droebachiensis caused dramatic declines in urchin densities, and communities previously barren were colonized by kelp and other macroalgae (Scheibling \& Hennigar 1997). Also in S. droebachiensis, major declines due to a parasitic nematode or some other waterborne agent led to kelp reestablishment in previously barren areas (Skadsheim et al. 1995). Populations of Diadema antillarum suffered a mass mortality throughout the Caribbean in 1983 due to an epidemic caused by an unknown waterborne pathogen (Lessios et al. 1984). This large-scale die-off led to Caribbean-wide shifts from coral dominated to algal dominated communities (Liddell \& Ohlhorst 1986, Hughes 1989).

\section{Taxa differ between barrens and kelp forests}

Kelp forests and barrens are easy to recognize as very different communities, with different habitats and food available for their constituent organisms. However, for some organisms the association with one community type or the other may be unclear without quantitative analysis. It is necessary to gain an understanding of the associations between individual species and the community type where they are most common in order to better understand the community structure and resources available within each community state.

The relatively high abundance of herbivores other than urchins in urchin barrens is not consistent with the expectation that community patterns on rocky reefs are driven by kelp as a food source. Some red algal taxa and rapidly colonizing species of green algae and diatoms ('Miscellaneous plants' in Table 2) were equally abundant in barrens and kelp forest communities and may support resident herbivores in the absence of kelp.

The higher abundance of 2 urchin predators in kelp forests is consistent with the general paradigm that kelp forests are maintained by trophic cascades. A surprising exception was the predatory fish Semicossyphus pulcher. Although these fish can significantly reduce urchin densities (Cowen 1983), it seems possible that they are able to track urchin densities. This could mask any association or lead to an association with barrens, since once an area has low urchin abundances and becomes a kelp forest, this urchin predator could move to forage in an area with higher urchin densities. It is also possible that the macroalgae present in forest sites impeded observations of fishes, thereby making it appear as if kelp forests had fewer fish than they actually did.

A quantitative evaluation of species associations with different community types can also lead to recognition of indirect effects and non-trophic interactions that lead to species abundance patterns. In this study, small anemones and cup corals were associated with barrens. Their relatively low abundance in kelp forests is likely due to decreased feeding resulting from mechanical disturbance of tentacles by algal fronds (Coyer et al. 1993). This then leads to an indirect effect of algae on abundance of cowry Cypraea spadicea which feed on small anemones (Morris et al. 1980). There are many similar associations due to indirect effects, e.g. between the bryozoan Diaperoecia californica and kelp forests, likely due to the bryozoan's tendency to grow on algae including Macrocystis pyrifera.

Our results generally agree with those of Graham (2004), who used presence-absence rather than abundance data. However, there are some importance differences. The dominant herbivores in this system, 
Strongylocentrotus franciscanus and S. purpuratus, are common throughout the Channel Islands, but more abundant in barrens; the present study detects this significant association, while an analysis of presenceabsence data finds no significant association. In contrast, the urchin Lytechinus anamesus is less widespread and was found to associate with barrens in both analyses. Graham (2004) further found that many more species are kelp forest obligates than barrens obligates. This may explain why many of the species he determined to be ubiquitous were found to associate with barrens in this study, since presence-absence data can mask potentially important species abundance patterns. However, due to the number of species for which he had presence-absence data, Graham (2004) was able to test associations in many more species and detect associations that we were not able to test (e.g. kelp forest associated fishes).

\section{CONCLUSIONS}

On temperate rocky reefs, kelp forests and barrens are alternative community states associated with characteristic organisms. When predators on urchins, such as spiny lobsters and sheephead, are fished, community transitions can occur. Therefore, protection from fishing via marine reserves can have community-wide effects, leading to kelp forests as the predominant community state in reserves, while barrens are the common community state in fished areas. Urchin disease also acts in a regulatory manner in this system. Disease was more common at fished sites where urchins were abundant, and epidemics tended to shift the community back toward a kelp forest state. Still, this did not have the same dramatic effect on community structure as predators did. This study illustrates that the effects of marine reserves reach far beyond single species fisheries effects and shows that through indirect effects and trophic cascades, reserves may play a role in conserving entire community types.

Acknowledgements. We thank S. D. Gaines, D. J. Kushner, D. C. Reed and A. A. Schaffner for valuable discussions, and the Channel Islands National Park for the use of data from the Kelp Forest Monitoring Program. Support was provided by the U.S. Geological Survey, the University of California Marine Council grant 01 T CEQI 081080 to M.D.B., and the National Science Foundation through the NIH/NSF Ecology of Infectious Disease Program (DEB-0224565) to K.D.L.

\section{LITERATURE CITED}

Babcock RC, Kelly S, Shears NT, Walker JW, Willis TJ (1999) Changes in community structure in temperate marine reserves. Mar Ecol Prog Ser 189:125-134
Cohen J (1960) A coefficient of agreement for nominal scales Educ Psych Meas 20:37-46

Cole RG, Keuskamp D (1998) Indirect effects of protection from exploitation: patterns from populations of Evechinus chloroticus (Echinoidea) in northeastern New Zealand. Mar Ecol Prog Ser 173:215-226

Cowen RK (1983) The effect of sheephead (Semicossyphus pulcher) predation on red sea urchins (Strongylocentrotus franciscanus) populations: an experimental analysis. Oecologia 58:249-255

Coyer JA, Ambrose RF, Engle JM, Carroll JC (1993) Interactions between corals and algae on a temperate zone rocky reef: mediation by sea urchins. J Exp Mar Biol Ecol 167:21-37

Davis GE, Kushner DJ, Mondragon JM, Mondragon JE, Lerma D, Richards D (1997) Kelp forest monitoring handbook, Vol 1: Sampling protocol. Channel Islands National Park, Ventura, CA

Duggins DO (1983) Starfish predation and the creation of mosaic patterns in a kelp dominated community. Ecology 64:1610-1619

Ebert TA (1977) An experimental analysis of sea urchin dynamics and community interactions on a rock jetty. J Exp Mar Biol Ecol 27:1-22

Elner RW, Vadas RL Sr (1990) Inference in ecology: the sea urchin phenomenon in the northwestern Atlantic Ocean. Am Nat 136:108-125

Estes JA, Tinker MT, Williams TM, Doak DF (1998) Killer whale predation on sea otters linking oceanic and nearshore ecosystems. Science 282:473-476

Gilles KW, Pearse JS (1986) Disease in sea urchins (Strongylocentrotus purpuratus): experimental infection and bacterial virulence. Dis Aquat Org 1:105-114

Graham MH (2004) Effects of local deforestation on the diversity and structure of southern California giant kelp forest food webs. Ecosystems 7:341-357

Halpern BS, Warner RR (2002) Marine reserves have rapid and lasting effects. Ecol Lett 5:361-366

Harrold C, Reed DC (1985) Food availability, sea urchin (Strongylocentrotus franciscanus) grazing and kelp forest community structure. Ecology 66:1160-1169

Holbrook SJ, Carr MH, Schmitt RJ, Coyer JA (1990) Effect of giant kelp on local abundance of reef fishes: the importance of ontogenetic resource requirements. Bull Mar Sci 47:104-114

Hughes TP (1989) Community structure and diversity of coral reefs: the role of history. Ecology 70:275-279

Klecka WR (1980) Discriminant analysis. Sage Publications, Beverly Hills, CA

Lafferty KD (2004) Fishing for lobsters indirectly increases epidemics in sea urchins. Ecol Appl 14(5):1566-1573

Lafferty KD, Kushner D (2000) Population regulation of the purple sea urchin, Strongylocentrotus purpuratus, at the California Channel Islands. In: Chang W (ed) 5th California Islands Symp. Minerals Management Service, Santa Barbara, CA

Lessios HA, Robertson DR, Cubit JD (1984) Spread of Diadema mass mortality through the Caribbean. Science 226:335-337

Liddell WD, Ohlhorst SL (1986) Changes in benthic community composition following the mass mortality of Diadema at Jamaica. J Exp Mar Biol Ecol 95:271-278

McClanahan TR, Shafir SH (1990) Causes and consequences of sea urchin abundance and diversity in Kenyan coral reef lagoons. Oecologia 83:362-370

McClanahan TR, Kamukuru AT, Muthiga NA, Yebio MG, Obura D (1996) Effect of sea urchin reductions on algae, coral, and fish populations. Conserv Biol 10:136-154 
McGarigal K, Cushman S, Stafford S (2000) Multivariate statistics for wildlife and ecology research. Springer-Verlag, New York

Morris RH, Abbott DP, Haderlie EC (1980) Intertidal invertebrates of California. Stanford University Press, Stanford, CA

Paine RT, Vadas RL (1969) The effect of grazing by sea urchins, Strongylocentrotus spp., on benthic algal populations. Limnol Oceanogr 14:710-719

Reed DC, Raimondi PT, Carr MH, Goldwasser L (2000) The role of dispersal and disturbance in determining spatial heterogeneity in sedentary organisms. Ecology 81: 2011-2026

Rice WR (1989) Analyzing tables of statistical tests. Evolution 43:223-225

Richards DV, Kushner D (1994) Kelp forest monitoring, 1992 annual report. Tech Rep CHIS-94-01, 20, Channel Islands National Park, Ventura, CA

Sala E, Zabala M (1996) Fish predation and the structure of the sea urchin Paracentrotus lividus populations in the NW Mediterranean. Mar Ecol Prog Ser 140: $71-81$

Sala E, Boudouresque CF, Harmelin-Vivien M (1998) Fishing, trophic cascades, and the structure of algal assemblages: evaluation of an old but untested paradigm. Oikos 82: 425-439

Scheibling RE, Hennigar AW (1997) Recurrent outbreaks of disease in sea urchins Strongylocentrotus droebachiensis in Nova Scotia: evidence for a link with large-scale meteorologic and oceanographic events. Mar Ecol Prog Ser 152:155-165

Schiel DR, Foster MS (1986) The structure of subtidal algal

Editorial responsibility: Otto Kinne (Editor),

Oldendorf/Luhe, Germany stands in temperate waters. Oceanogr Mar Biol Annu Rev 24:265-307

Shears NT, Babcock RC (2002) Marine reserves demonstrate top-down control of community structure on temperate reefs. Oecologia 132:131-142

Shears NT, Babcock RC (2003) Continuing trophic cascade effects after 25 years of no-take marine reserve protection. Mar Ecol Prog Ser 246:1-16

Silliman BR, Bertness MD (2002) A trophic cascade regulates salt marsh primary production. Proc Natl Acad Sci USA 99: 10500-10505

Skadsheim A, Christie H, Leinaas HP (1995) Population reductions of Strongylocentrotus droebachiensis (Echinodermata) in Norway and the distribution of its endoparasite Echinomermella matsi (Nematoda). Mar Ecol Prog Ser 119:199-209

SPSS (2000) SPSS for Windows release 10.1.0. SPSS, Chicago, IL

Tegner MJ, Dayton PK (1981) Population structure, recruitment and mortality of two sea urchins (Strongylocentrotus franciscanus and $S$. purpuratus) in a kelp forest. Mar Ecol Prog Ser 5:255-268

Tegner MJ, Dayton PK (2000) Ecosystem effects of fishing in kelp forest communities. ICES J Mar Sci 57:579-589

Tegner MJ, Levin LA (1983) Spiny lobsters and sea urchins: analysis of a predator-prey interaction. J Exp Mar Biol Ecol 73:125-150

Watanabe JM, Harrold C (1991) Destructive grazing by sea urchins Strongylocentrotus spp. in a central California kelp forest: potential roles of recruitment, depth, and predation. Mar Ecol Prog Ser 71:125-141

Williams BK (1983) Some observations on the use of discriminant analysis in ecology. Ecology 64:1283-1291

Submitted: October 22, 2003; Accepted: July 13, 2004

Proofs received from author(s): September 17, 2004 